\title{
3 Dimensional Dynamic Map on Buildings at University of Darussalam Gontor Based on Augmented Reality
}

\author{
Peta Dinamis 3 Dimensi pada Gedung Universitas Darussalam Gontor Berbasis \\ Augmented Reality
}

\author{
Received: \\ 1 December 2020 \\ Revised: \\ 22 July 2021 \\ Published:
}

8 August 2021

\author{
1*Faisal Reza Pradhana, ${ }^{2}$ Taufiqurrahman, ${ }^{3}$ Ady Fauzan \\ 1,2,3 Teknik Informatika,Universitas Darussalam Gontor \\ 1,2,3Ponorogo, Indonesia \\ E-mail: ${ }^{1}$ faisalrezapradhana@ unida.gontor.ac.id, \\ ${ }^{2}$ taufiqurrahman@unida.gontor.ac.id, ${ }^{3}$ Ady@unida.gontor.ac.id
}

\begin{abstract}
Darussalam Gontor University (Unida Gontor) is a campus with a fairly rapid development of infrastructure. The paper-based building prototype design belonging to UNIDA Gontor is considered not able to visually represent the building that has been or will be built. This research aims to provide a prototype design update using more modern and dynamic technology that can be seen from all sides of the building and does not require physical storage, also can be used anytime and anywhere.The Application content is taken through the visual data collection stage in the form of detailed photos of buildings taken through cameras and drones. This media is based on Android which uses marker based augmented reality technology to implement 3-dimensional visualization of campus building objects, which are created through the steps of the waterfall model. The test is carried out in two stages, namely the suitability of the application with various android devices which shows compatibility with devices with a minimum size of 5 inches. The second test was conducted by distributing questionnaires to the staff of the facilities and infrastructure division of Unida Gontor with an average score of $90 \%$, and the lecturers and multimedia student group $89.52 \%$.
\end{abstract}

Keyword-3D maps, Augmented reality, Android, Mobile Programming

Abstrak - Universitas Darussalam Gontor (Unida Gontor) merupakan kampus dengan perkembangan sarana prasarana yang cukup pesat. Desain purwarupa bangunan berbasis kertas milik UNIDA Gontor dinilai belum dapat merepresentasikan secara visual bangunan yang sudah atau akan dibangun. Penelitian ini bertujuan untuk memberikan pembaruan desain prototipe dengan menggunakan teknologi yang lebih modern dan dinamis yang dapat dilihat dari segala sisi bangunan dan tidak memerlukan penyimpanan dalam bentuk fisik serta mampu digunakan kapanpun dan dimanapun. Konten aplikasi diambil melalui tahap pengumpulan data visual berupa foto detail gedung yang diambil melalui kamera dan drone. Media berbasis android ini menggunakan teknologi augmented reality berbasis marker untuk memvisualisasikan 3D objek gedung kampus yang dibuat melalui tahapan model waterfall. Pengujian dilakukan dalam dua tahap yaitu kesesuaian aplikasi dengan berbagai perangkat android yang menunjukkan kesesuaian dengan perangkat dengan ukuran minimal 5 inch. Tes kedua dilakukan dengan menyebarkan angket kepada staf bagian sarana dan prasarana Unida Gontor dengan skor ratarata 90\%, dosen dan kelompok mahasiswa multimedia $89.52 \%$.

Kata Kunci-Peta 3D, Augmented Reality, Android, Pemograman Mobile 
INTENSIF, Vol.5 No.2 August 2021

ISSN: 2580-409X (Print) / 2549-6824 (Online)

DOI: https://doi.org/10.29407/intensif.v5i2.15327

\section{INTRODUCTION}

Within 6 years, UNIDA Gontor has built 7 new buildings to meet the needs of campus facilities and infrastructure[1]. The speed of construction must be balanced with the availability of a building master plan design and construction that is detailed, dynamic and has a visual that can represent a real building model.The model design is needed to anticipate all needs, such as updates or required maintenance. The prototype design owned by UNIDA Gontor is still in paper form, which is considered not to clearly represent the shape of the building. This design is quite difficult to understand, especially for lay users who are not experts in the field of architecture. Paper prototype designs are also prone to loss or damage, and have a high level of difficulty in handling design additions and developments when needed quickly. A solution that can meet these needs is to take advantage of computer technology which continues to grow very rapidly these days, one of them is augmented reality (AR) technology. AR technology allows us to be able to display 3-dimensional objects into real views and in real time. In addition, AR technology has the advantage of being easy to use without requiring too many tools[2].

A 3-dimensional digital objects are selected in the model design, based on the advantage of being able to be monitored from all sides, thus providing a detailed and comprehensive picture for potential users[3]. Android was chosen as the basis for this application because Android is the operating system most widely used by the world community today, Android applications have been used for many purposes, such as entertainment, education, business, health etc[4]. It is noted that Android applications have been used by more than 170 countries in the world and recorded $70 \%$ of the use of smartphone operating systems. Another advantage of Android is that it has an open source license so that developers have freedom in terms of development and innovation[5]. The choice of the Android operating system as the application base is also in line with the increase in smartphone users in the world, which has increased by more than $60 \%$ of the use of digital devices, this shows that smartphone is the most widely used digital device compared to other devices in the world[6]. Based on the various facts above, it is hoped that this application can be the best solution and the answer to all needs.

A study related to the use of augmented reality technology in temple buildings, shows a usability level of 8.4 out of 10 , this shows that AR technology is easy to understand and use by users. Augmented Reality application interface proven capable to complete the assigned task properly, and make it easy to learn [7]. In other research about the application of sunnah based on augmented reality technology, showed an increase in interest in implementing sunnah from $25 \%$ to $34 \%$, as well as an increase in knowledge of sunnah up to $92 \%$. This increase is based on attractive AR application features, both in terms of 3-dimensional objects and interface design 
that are very popular with users, especially teenagers[8]. In another research, it was stated that 3dimensional modeling has advantages compared to 2-dimensional models, where 3-dimensional media can provide real-world experiences, concrete presentations and avoid verbalism, able to show the object as a whole with good construction and how it works, able to clearly show the organizational structure, and able to show a clear process flow[9].

Mentioned in a research related to the development of 3-dimensional objects in animal and plant cells, that some of the aspects possessed by $3 \mathrm{D}$ objects that can attract users to study them are the attractiveness of colors, backgrounds, images, and animation. Suitability of size Image, Image exposure accuracy and movement speed[10]. Other Research explained on the use of Augmented reality technology to identify types of medicinal plants that a $3 \mathrm{D}$ object can be displayed perfectly when highlighted at a distance of $10 \mathrm{~cm}$ with $0^{\circ}$ angle and lighting criteria sunshine (cloudy). While lighting (dark) objects will be displayed at a distance of $15 \mathrm{~cm}$ and angle $0^{\circ}[11]$.

The novelty of this research is an optimization of several previous studies in the use of augmented reality for building construction, from design aspects, features aspects, color aspects, detailed model aspects, application suitability aspects and the ease of using applications adapted to various users, evidenced by the evaluation results are quite good and the application can be accepted by potential users. The use of augmented reality technology is expected that the building master plan will have adaptive and dynamic charasteristic. The dynamics here are that the building design master plan can be accessed easily, anywhere and anytime using a smartphone, without the hassle of carrying the design on paper.

\section{RESEARCH METHOD}

\section{A. Sources}

The 3-dimensional modeling in this research uses a blender application, blender is an open source licensed application, specifically for computer modeling, animation and 3D graphics creation [12]. The markers of augmented reality that have been designed will be inserted into the target image database contained in the Vuforia Developer[13].This application is run on the android operating system version 5.0 and above, and runs on devices with a minimum size of 5 inches, this application is run on the android operating system version 5.0 and above, and is run on devices with a minimum size of 5 inches, using the android Studio development kit (SDK) as a platform development tool and as an Application Programming Interface (API)[14]. The target marker card design uses Adobe Photoshop software, an image processing application from the Adobe System devoted to photo / image editing[15]. Merging 3-dimensional objects and target markers using unity $3 \mathrm{~d}$ software, a cross-platform based game engine that can be used to create 
INTENSIF, Vol.5 No.2 August 2021

ISSN: 2580-409X (Print) / 2549-6824 (Online)

DOI: https://doi.org/10.29407/intensif.v5i2.15327

interactive games and applications that can be used on computer devices, Android smartphones, iPhone, PS3, and even the X-BOX[16].

B. Methods

The research method using System Development Life Cycle (SDLC), also known as the waterfall approach, consists of several stages, namely (1) requirements, (2) design, (3) implementation, (4) verification, (5) maintenance[17].

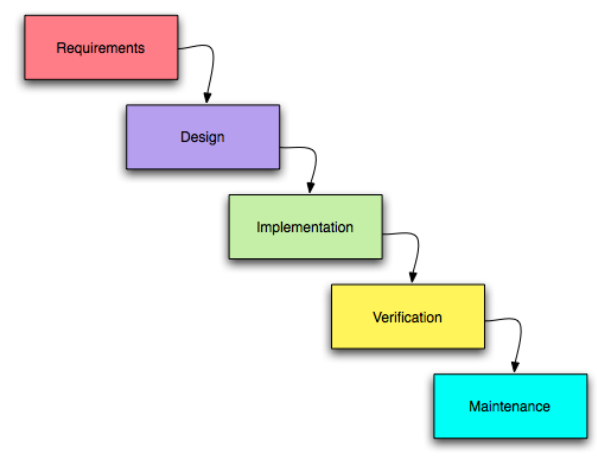

Figure 1. WATERFALL MODEL

\section{Requirements}

At the requirement stage, data was collected by conducting interviews with the facilities and infrastructure staff of UNIDA Gontor. as well as making observations on university buildings in the form of photo portraits of buildings from each side, as materials for designing 3-dimensional models.

\section{Design}

The design stage is carried out after the data needs are met, the activities at this stage are designing a 3D model of buildings, system architecture diagrams, use cases and activity diagrams, as well as designing target markers for the needs of 3D object recognition, also designing the interface design of the mobile application that will be used.

\section{Implementation}

This stage implements every $3 \mathrm{~d}$ building model that has been made into the mobile application and registers each target marker card into the vuforia application so that it can be recognized by the system. It is hoped that at this stage, the 3D building mobile application has been completed in beta form.

\section{Verification}

Application testing is carried out at this stage, by testing the compatibility level of the application with various sizes of android devices, as well as testing the application to potential users and multimedia experts to get corrections and suggestions. the verification data obtained by distributing questionnaires. 
INTENSIF, Vol.5 No.2 August 2021

ISSN: 2580-409X (Print) / 2549-6824 (Online)

DOI: https://doi.org/10.29407/intensif.v5i2.15327

5. Maintenance

At this stage, the application is refined based on input from the results of the questionnaire that has been distributed at the verification stage. Treatment is carried out regularly to get satisfactory results.

The augmented reality method used is marker based augmented reality, markers that have been designed will be inserted into the target image database contained in the Vuforia Developer[13].

\section{RESULT AND DISCUSSION}

\section{A. Requirement}

Table 1 is an exploratory stage, starting from problem identification to technology solutions used in the development of this augmented reality application. Initial exploration starts from exploring problems by conducting interviews and distributing pre-research questionnaires to the facilities and infrastructure section of UNIDA Gontor, which concludes the need to develop an augmented reality application for building master plans at UNIDA Gontor.

Table 1. THE NEEDS FOR APPLICATION DEVELOPMENT

\begin{tabular}{lll}
\hline \multirow{2}{*}{ No } & \multicolumn{2}{c}{ Application Development Needs } \\
\cline { 2 - 3 } & Activities & $\begin{array}{l}\text { Result } \\
\text { fhe prototype design } \\
\text { fontor development } \\
\text { master plan is still in } \\
\text { the form of paper } \\
\text { which is vulnerable } \\
\text { to damage and less } \\
\text { dynamic }\end{array}$ \\
\hline \multirow{2}{*}{ d } & Problem identification & $\begin{array}{l}\text { 3 Dimensional } \\
\text { dynamic map of } \\
\text { Building masterplan }\end{array}$ \\
\hline 3 & Offered Solution & $\begin{array}{l}\text { System Development } \\
\text { Life Cycle }\end{array}$ \\
\hline 4 & Used Method & Augmented reality \\
\hline
\end{tabular}

After completing problem identification stage, it is continued with the visual building data collection stage. Visual sampling is done using cameras and drones, aerial photos taken from drone provide a side view of the building along with the whole that is around him that is more real, and capable provides a wider viewpoint[18]. An example of the results of visual building data collection can be seen in Figure 2 below. 
INTENSIF, Vol.5 No.2 August 2021

ISSN: 2580-409X (Print) / 2549-6824 (Online)

DOI: https://doi.org/10.29407/intensif.v5i2.15327

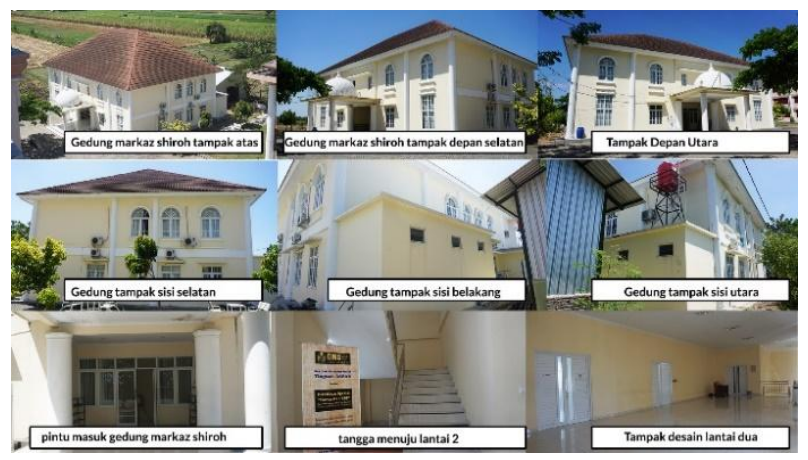

Figure 2. AN EXAMPLE OF VISUAL DATA BUILDING COLLECTION

All the results of building visual data collection are processed into 3-dimensional assets using blender software, an example of the 3-dimensional building asset design process can be seen in Figure 3 below.

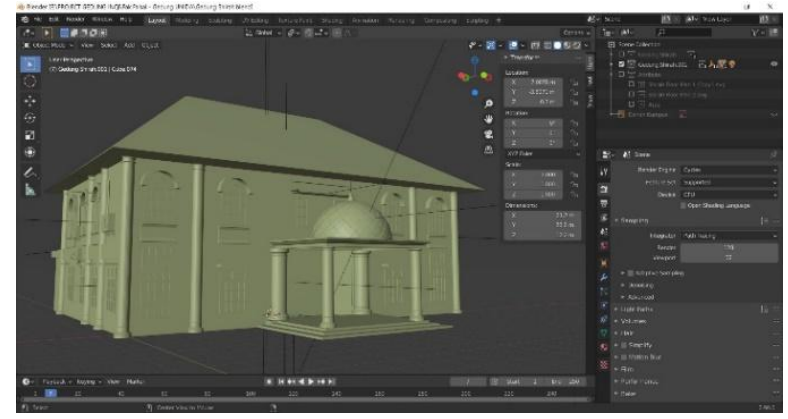

Figure 3. PROCESSING 3D ASSET BUILDING ON BLENDER

Every 3-dimensional asset design must pay attention to various aspects, including building details, color, suitability of building details with the original object, all of these things are absolutely necessary, so that the expected results are on target and can be used immediately by the user. an example of a comparison of the original photo image with $3 \mathrm{~d}$ assets can be seen in Figure 4 below.

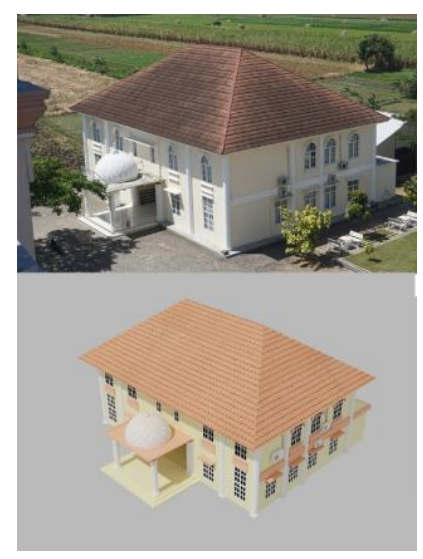


INTENSIF, Vol.5 No.2 August 2021

ISSN: 2580-409X (Print) / 2549-6824 (Online)

DOI: https://doi.org/10.29407/intensif.v5i2.15327

Figure 4. A COMPARISON BETWEEN REAL PHOTOS AND 3D ASSET OF BUILDING

\section{B. Design}

When data needs have been met, the next step is to create a flow and steps for using the application, in Figure 5 below describes the relationships between components, aimed of providing a comprehensive view of the system to be developed, in the form of a system architecture diagram[19].

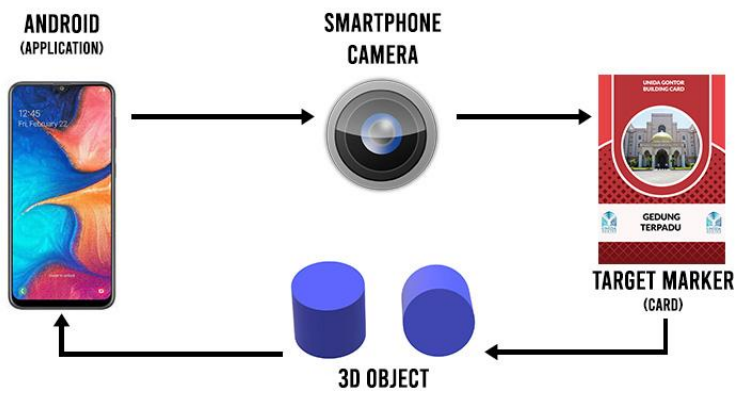

Figure 5. A SYSTEM ARCHITECTURE DIAGRAM

The next step is to prepare a sequence in the system to be built, by explaining the behavior desired by the user, and the flow of activity in the system designed that involve user or user action In using the application, Figures 6 and 7 below explain the use case and activity diagram of the application[20].

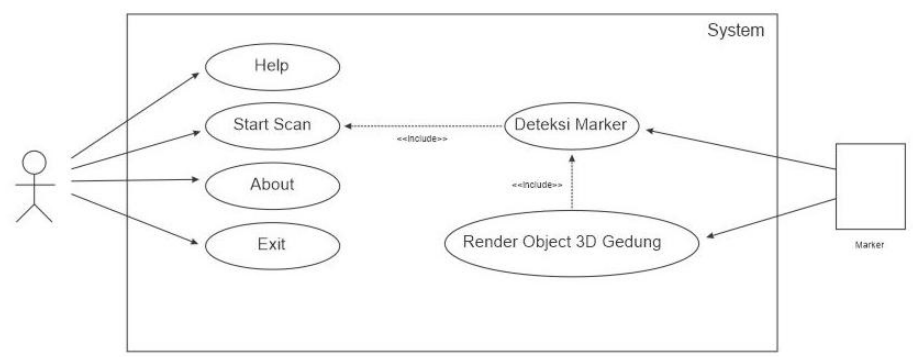

Figure 6. USE CASE DIAGRAM 
INTENSIF, Vol.5 No.2 August 2021

ISSN: 2580-409X (Print) / 2549-6824 (Online)

DOI: https://doi.org/10.29407/intensif.v5i2.15327

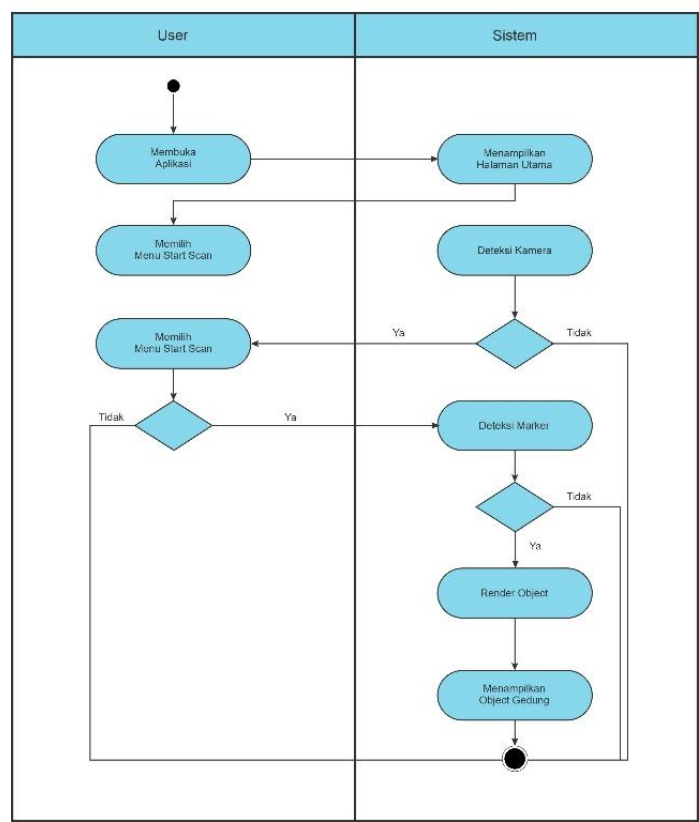

Figure 7. ACTIVITY DIAGRAM

The next step is to design a target marker, the target market is an object, often a card that will be used in the tracking process for a 3-dimensional object, tracking marker is a process carried out by the system when doing image scan to an existing database. In this case Vuforia as the provider service performs the tracking marker process[21]. The target application markers are shown in Figure 8 below.

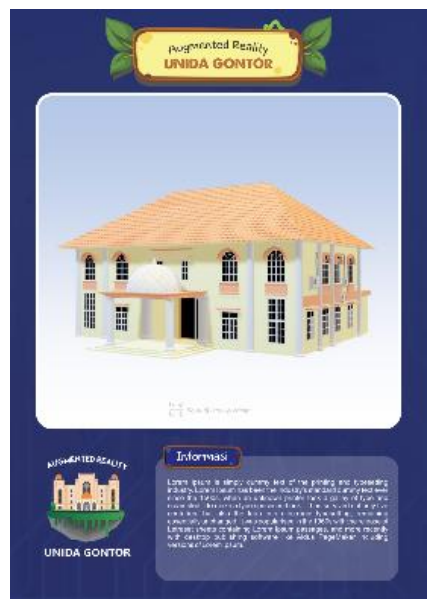

Figure 8. TARGET MARKER

C. Implementation

Figure 9 displays the application's main menu design, when opening the application, the user will be presented with several buttons such as home, help, scan, about and exit buttons. also displayed main building design as logo. 
INTENSIF, Vol.5 No.2 August 2021

ISSN: 2580-409X (Print) / 2549-6824 (Online)

DOI: https://doi.org/10.29407/intensif.v5i2.15327

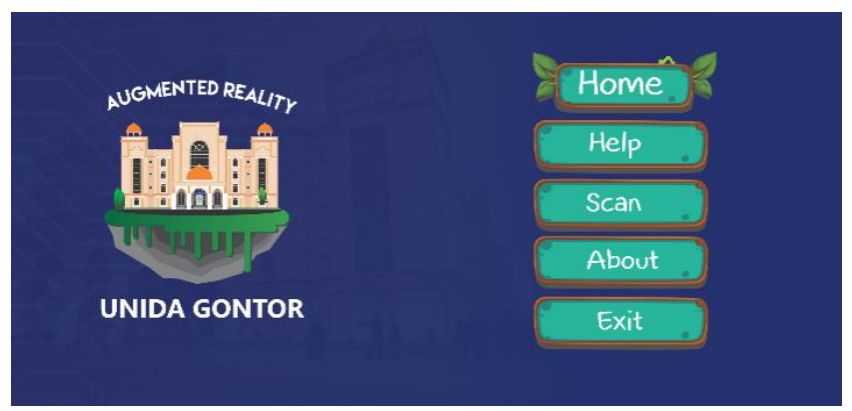

Figure 9. MAIN MENU

Figure 10 displays a scan page, a 3-dimensional building object will appear here, according to the target marker that is tracked using an application via a smartphone camera.

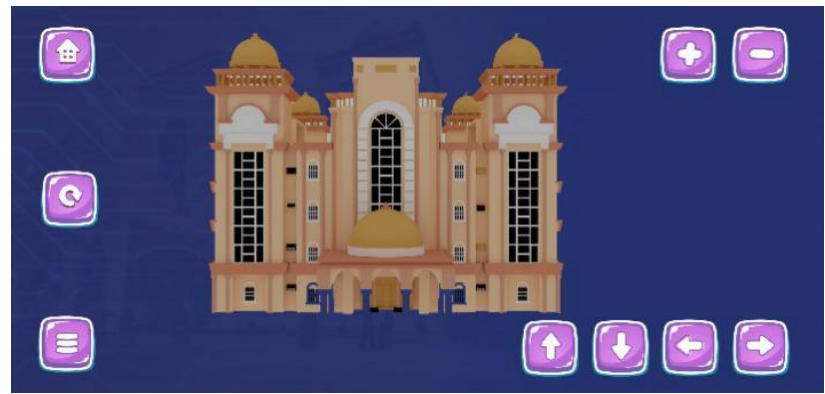

Figure 10. SCAN MENU

Figure 11 displays about and help menu page, on this page the application specifications will be explained along with all related information. On the help menu, several guides are displayed on how to use the application. This page is prepared to make it easier for users to run the application, and to get a complete guide when experiencing problems during operations.
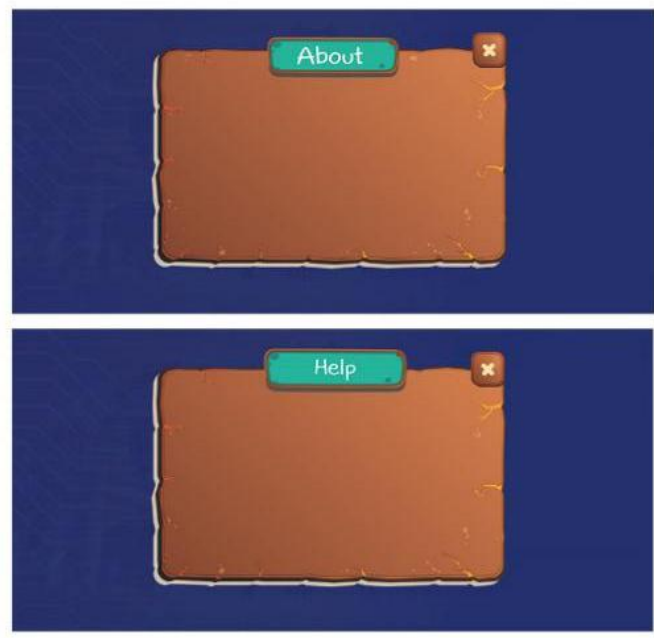

Figure 11. ABOUT AND HELP MENU 
INTENSIF, Vol.5 No.2 August 2021

ISSN: 2580-409X (Print) / 2549-6824 (Online)

DOI: https://doi.org/10.29407/intensif.v5i2.15327

\section{Verification}

Table 2 shows the results of the trial process of installing applications to several Android devices, it was concluded the level of compatibility of this application with devices with a screen size of at least 5 inches.

Table 2. SOFTWARE FUNCTIONALITY TEST RESULT

\begin{tabular}{lcc}
\hline \multirow{2}{*}{ Device Types } & \multicolumn{2}{c}{ Device Details } \\
\cline { 2 - 3 } & Screen Size & Result \\
\hline Samsung A20 & 6,4 & Success \\
\hline Oppo F3 & 5,5 & Success \\
\hline Vivo V15 & 6,5 & Success \\
\hline Samsung Galaxy J7 & 5,5 & Success \\
\hline Xiaomi Redmi 5A & 5 & Success \\
\hline Xiaomi MI A2 & 5,99 & Success \\
\hline Samsung Galaxy S Duos3 & 4,3 & Failed \\
\hline Samsung Galaxy J5 & 5 & success \\
\hline
\end{tabular}

Test on the Samsung Galaxy S smartphone Duos 3declared a failure because it does not meet the needs of the application system, where it takes at least a 5 inch smartphone screen size.

The next test aims to check from design aspects, features aspects, color aspects, aspects detailed model, application suitability aspects. This test is carried out by distributing questionnaires given to lecturer and student from multimedia study club of UNIDA Gontor, selected based on their level of ability and achievement in the multimedia field, and are expected to be able to provide input related to aesthetic design, features and coloring. It is hoped that by holding this test, data on the suitability of the application to user needs can be obtained, and it can be seen that the evaluation and input of each prospective user will further enhance the augmented reality application. The test result known by giving an average rating of $0-40$ for the poor category, 41-50 for the marginal category, 51-70 for the good category, 71-90 for very good, and $91-100$ for the perfect score. the average test results of 89.52 indicate that this application is feasible to use. The test results are shown in the table 3 below.

Table 3. SUITABILITY OF APPLICATION FUNCTIONS TEST

\begin{tabular}{lcc}
\hline \multirow{2}{*}{ Types of questionaire } & \multicolumn{2}{c}{ indicator } \\
\cline { 2 - 3 } & Average Score & Result \\
\hline Apps Presentation & 90 & Very Good \\
\hline Application features & 89.85 & Very Good \\
\hline Ease of use & 90 & Very Good \\
\hline Objek detail level & 88.76 & Very Good \\
\hline
\end{tabular}


INTENSIF, Vol.5 No.2 August 2021

ISSN: 2580-409X (Print) / 2549-6824 (Online)

DOI: https://doi.org/10.29407/intensif.v5i2.15327

\begin{tabular}{lcc}
\hline \hline \multirow{2}{*}{ Types of questionaire } & \multicolumn{2}{c}{ indicator } \\
\cline { 2 - 3 } & Average Score & Result \\
\hline Data suitability & 89.28 & Very Good \\
\hline Writing Clarity & 89.85 & Very Good \\
\hline Color Suitability & 90 & Very Good \\
\hline User Motivation & 88.42 & Very Good \\
\hline
\end{tabular}

Test is also aimed at 8 staff of the infrastructure division of UNIDA Gontor as potential users of this application, aiming to find out whether the application that has been designed can meet the needs and can update the blueprint design of building paper that has been previously owned, testing is carried out by distributing questionnaires that show the results an average of $90 \%$, so that It can be said that this application can be accepted as the future infrastructure development designs that are easier, more structured, dynamic and adaptive. the results of the staff questionnaire can be shown in Figure 12 below.

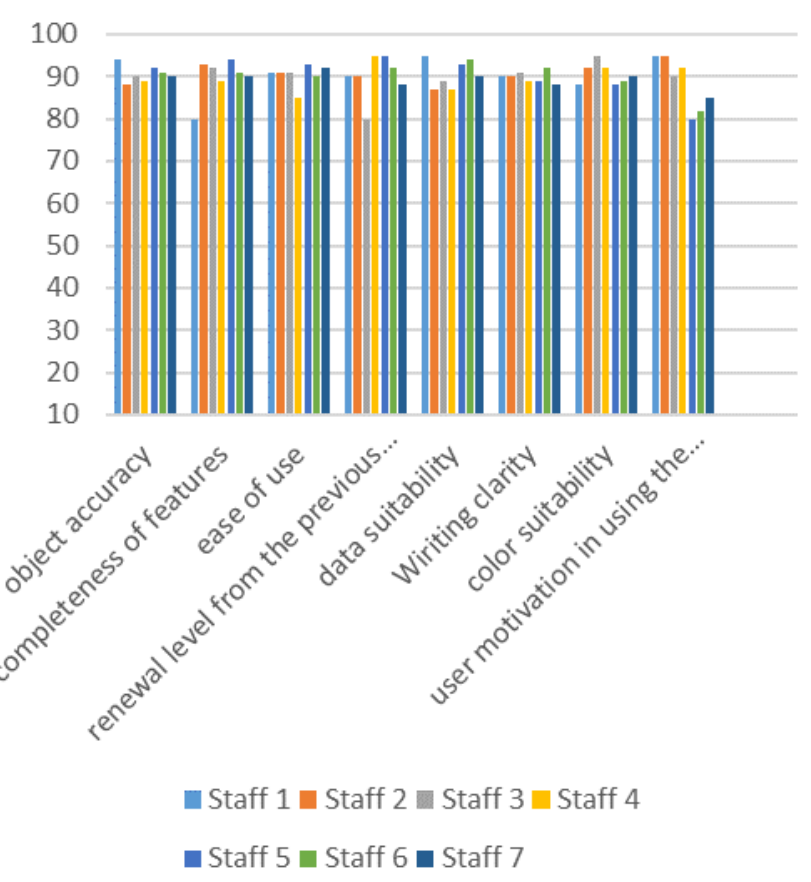

Figure 12. RESULT OF ASSESSMENT FROM INFRASTRUCTURE STAFF OF UNIDA GONTOR

\section{E. Maintenance}

The last phase is to improve the detail level of the 3D object some input from users through input sessions and questionnaires. Until now, there have been 2 revisions to the details of the dormitory building and the color of target marker. 
INTENSIF, Vol.5 No.2 August 2021

ISSN: 2580-409X (Print) / 2549-6824 (Online)

DOI: https://doi.org/10.29407/intensif.v5i2.15327

\section{CONCLUSION}

Based on the results of several tests, it can be concluded that this application is feasible to use, and is able to function as a renewal model of the paper-based building blueprint previously owned by UNIDA Gontor, indicated by the results of the evaluation through questionnaires distributed on design aspects, features aspects, color aspects, aspects detailed model, application suitability aspects which received an average value of 89.52 , and the evaluation results of potential users showed an average value of 90 indicating that this application according to user requirements. We hope that in the future this research can be improved by adding the design of electricity and water line infrastructure, so that it can complement the usefulness of this dynamic 3D model in many ways and functions.

\section{REFERENCES}

[1] B. S. P. U. D. Gontor, Dokumen Masterplan Pembangunan Universitas Darussalam Gontor, 2nd ed. Ponorogo: Universitas Darussalam Gontor, 2019.

[2] Y. Suciliyana et al., "AUGMENTED REALITY SEBAGAI MEDIA PENDIDIKAN SCHOOL-AGE," vol. 2, no. 1, pp. 39-53, 2020.

[3] K. N. Sistem et al., "Visualisasi Animasi 3D Sebagai Promosi Produk Desain Interior Pada Perusahaan $8^{\circ}$ South Kitchen \& Home Cabinetry Manufacturer," pp. 501-506, 2017.

[4] A. Relawati and G. M. Zamroni, "Development of Android Based Online Nurse Test Preparation," vol. 8, pp. 111-120, 2020.

[5] D. Muriyatmoko, F. R. Pradhana, and Z. A. Musyafa', "Durus Al-Lughah Gontory: Media Pembelajaran Bahasa Arab untuk Pemula Menggunakan Metode Langsung," J. Teknol. Inf. dan Ilmu Komput., vol. 6, no. 1, p. 77, Jan. 2019, doi: 10.25126/jtiik.2019611259.

[6] A. Fauzan, D. Muriyatmoko, and S. Nahwa Utama, "PENERAPAN TEKNOLOGI AUGMENTED REALITY ELSE ( Elementary School Education Journal )," vol. 4, pp. 63-78, 2020.

[7] D. A. Firmansyah, H. Tolle, and A. Pinandito, "Rancang Bangun Aplikasi Informasi Candi berbasis Teknologi Augmented Reality pada Smartphone Android ( Studi Kasus : Candi Ngetos , Nganjuk )," vol. 2, no. 8, pp. 2651-2658, 2018.

[8] F. W. Christanto, M. F. Affandi, and T. Winarti, "Image Tracking Berbasis Augmented Reality Untuk Relasi Antara Sunnah Nabi dan Manfaat Secara Medis," JUITA J. Inform., vol. 8, no. 1, p. 75, 2020, doi: 10.30595/juita.v8i1.5541.

[9] I. F. Faiztyan, R. R. Isnanto, and E. D. Widianto, "Perancangan dan Pembuatan Aplikasi Visualisasi 3D Interaktif Masjid Agung Jawa Tengah Menggunakan Unity3D," J. Teknol. dan Sist. Komput., vol. 3, no. 2, p. 207, 2015, doi: 10.14710/jtsiskom.3.2.2015.207-212.

[10] A. History, "PENGEMBANGAN MEDIA OBYEK 3 DIMENSI DIGITAL SEL HEWAN DAN TUMBUHAN MEMANFAATKAN," vol. 2, no. 1, pp. 9-15, 2019.

[11] R. Efendi, "Rancang Bangun Aplikasi Augmented Reality Untuk Deteksi Pengenalan Tanaman Obat Berbasis Android," IKRA-ITH Inform., vol. 4, no. 1, pp. 35-45, 2020.

[12] D. Suhenra, M. Ahyar, and M. M. Parenreng, Penerapan Augmented Reality sebagai Media Pengenalan Kampus Politeknik Negeri Ujung Pandang, no. September. 2018.

[13] A. Pramono and M. D. Setiawan, "Pemanfaatan Augmented Reality Sebagai Media 
Pembelajaran Pengenalan Buah-Buahan,” INTENSIF J. Ilm. Penelit. dan Penerapan Teknol. Sist. Inf., vol. 3, no. 1, p. 54, 2019, doi: 10.29407/intensif.v3i1.12573.

[14] D. Abdullah, A. Sani, and A. Hasan, "Pemanfaatan Teknologi Augmented Reality Pada Media Pengenalan Bangunan Bersejarah Rumah Kediaman Bung Karno Bengkulu Berbasis Android," Pseudocode, vol. 6, no. 1, pp. 21-29, 2019, doi: 10.33369/pseudocode.6.1.21-29.

[15] Edryanto, Irawan, and Effiyaldi, "Perancangan Aplikasi Augmented Reality Pengenalan Landmark Asia Tenggara Berbasis Android Pada Sdn 139/Iv Jambi,” J. Ilm. Mhs. Tek. Inform., vol. 2, no. 1, pp. 31-42, 2020.

[16] T. A. Ananda, N. Safriadi, and A. S. Sukamto, "Penerapan Augmented Reality Sebagai Planet-Planet Di Tata Surya," J. Sist. dan Teknol. Inf., vol. 1, no. 1, pp. 1-6, 2015.

[17] Y. Bassil, "A Simulation Model for the Waterfall Software Development Life Cycle," vol. 2, no. 5, May 2012.

[18] B. Subakti, "PEMANFAATAN FOTO UDARA UAV UNTUK PEMODELAN BANGUNAN 3D DENGAN METODE OTOMATIS," Spectra, vol. XV, no. 30, pp. 1530, 2017.

[19] L. Leonardi, Adrian; Hermawan, "Penerapan Augmented Reality Pada Brosur Interior Berbasis Multi Markerless Pada Android," Semin. Nas. Teknol. Inf. dan Komun. 2019, vol. 2019, no. Sentika, pp. 13-14, 2019.

[20] D. Dewantoro, S. Andryana, and A. Gunaryati, "Visualisasi Gedung Sekolah 3D dengan Konsep Virtual Reality Berbasis Android," J. Media Inform. Budidarma, vol. 4, no. 1, p. 42, 2020, doi: 10.30865/mib.v4i1.1866.

[21] C. A. Oktavia, R. F. Setiawan, and A. Christianto, "Perancangan Aplikasi Augmented Reality Untuk Pengenalan Ruangan Menggunakan Marker 3D Objects Tracking,” J. Ilm. Teknol. Inf. Asia, vol. 13, no. 1, p. 53, 2019, doi: 10.32815/jitika.v13i1.332. 